\title{
Temperature Monitoring System for Egg Incubators Using Raspberry Pi3 Based on Internet of Things (IoT)
}

\author{
Siti Purwanti ${ }^{1}$, Anita Febriani ${ }^{2}$, Mardeni ${ }^{3}$, Yuda Irawan ${ }^{4 *}$ \\ 1,2,3 Department of Information System, STMIK Hang Tuah Pekanbaru, Pekanbaru, Indonesia \\ ${ }^{4}$ Department of Computer Science, STMIK Hang Tuah Pekanbaru, Pekanbaru, Indonesia \\ Email: ${ }^{1}$ sitipurwanty05@gmail.com, ${ }^{2}$ nitasuheri@ gmail.com, ${ }^{3}$ mdn@htp.ac.id, \\ 4yudairawan89@gmail.com \\ *Corresponding Author
}

\begin{abstract}
The incubator is made as a substitute for hatching naturally at the same time. The success of the hatch machine is largely determined by the temperature stability in the incubator. In the use of small-scale hatcheries for native chicken hatching, they are still faced with the problem of low hatchability due to one of the obstacles, namely the power outage during the hatching process. To improve the monitoring performance of egg incubators, the writer wishes to conduct research "Monitoring to Control and Monitor Temperature in Egg Incubators" using a webcam camera to monitor temperature conditions and hatch eggs. The working system is the DHT11 sensor will detect the temperature, the webcam camera in real time will monitor the state of the eggs then the raspberry pi3 will automatically control the temperature and electrical energy on the incubator, the smartphone monitors and can also control the temperature with the state of the eggs in realtime, $12 \mathrm{~V}$ battery as a replacement energy when the PLN goes out. From the results of the tests carried out, the authors can draw conclusions, namely: The webcam camera can display the condition of the eggs in the incubator room. Android smartphones can receive information with a webcam camera during the hatching process. The data logger can display recapitulated temperature and humidity data.
\end{abstract}

Keywords- IoT, Raspberry Pi3, Egg Incubators, Temperature, Microcontroller.

\section{INTRODUCTION}

In the development of technology has developed rapidly as well as hatchery technology which has been able to create an artificial incubator known as the egg incubator (incubator), which can completely imitate the behavior of the hen during the incubation period [1]. The incubator is made as a substitute for hatching naturally at the same time [2]. The success of the hatch machine is largely determined by the temperature stability in the incubator [3]. In the use of smallscale hatcheries for native chicken hatching, they are still faced with the problem of low hatchability due to one of the obstacles, namely the power outage during the hatching process [4].

Automatic egg incubators that are widely used are better than incubating eggs with a stable temperature of $\pm 39^{\circ} \mathrm{C} \mathrm{[5]}$. However, there are also weaknesses in the egg incubator because the temperature in the egg incubator can result in chicks that have hatched to die if they are too long in the machine [6]. For this reason, it is necessary to innovate an egg incubator that is more effective and efficient in monitoring the development conditions of the egg being incubated [7]. So that chicken farmers can monitor the condition of the eggs that have hatched in real time so that the chicks do not experience death. In previous research [8] designed an arduino-based automatic egg incubator using a DHT11 sensor as a sensor that can measure two environmental parameters at once, namely temperature and humidity sensors that can detect the temperature that enters the temperature well [9]. incubator room as desired, namely $39^{\circ} \mathrm{C}$ [10]. To improve the monitoring performance of egg incubators, the writer wishes to conduct research "Monitoring to Control and Monitor Temperature in Egg Incubators" using a webcame camera to monitor temperature conditions and hatch eggs [11]. The working system is the DHT11 sensor will detect the temperature, the webcam camera in real time will monitor the state of the eggs then the raspberry pi3 will automatically control the temperature and electrical energy on the incubator [12], the smartphone monitors and can also control the temperature with the state of the eggs in realtime, $12 \mathrm{~V}$ battery as a replacement energy when the PLN goes out [13]. With this tool it can help and make it easier to check the temperature on the egg incubator and can control the temperature on the egg incubator so that the temperature on the egg incubator can be maintained properly and produce normal and quality egg hatching [14].

\section{METHODS}

The method that researchers use is the prototype method in order to be closer to the customer [15].

\section{Collection of Needs}

The client and the developer jointly define the software format, identify requirements and the system created [16].

\section{Build a prototype}

Building prototypes by making temporary designs that focus on serving customers, for example, such as making input and output formats.

\section{Evaluation of the prototype}

This stage is carried out by the client, whether the prototype is built, according to customer wants and needs. If it is not suitable, the prototype will be revised by repeating 
the previous steps, but if it is suitable, the next steps will be carried out [17].

\section{Encoding the system}

At this stage the prototype that has been agreed upon is translated into the appropriate programming language.

\section{Test the system}

After coding, of course, testing will be carried out. There are many ways to perform testing, for example using a white box or black box. Using a white box means coding testing is carried out while using a black box means testing display functions.

\section{System evaluation}

Evaluating all the steps taken. Is it in accordance with the needs or not. If it is not suitable, then it can be repeated in steps 1 and 2 .

\section{Use of the system}

The system that has been tested and accepted by the client is ready for use and don't forget to do maintenance so that the system is maintained and functions as it should.

The creation of a prototype for system developers aims to collect information from users so that users can interact with the prototype model being developed, because the prototype describes the initial version of the system with the aim of continuing to a larger real system [18].

\section{IMPLEMENTATION}

Implementation is one of the stages in system development, where this stage is the stage of the temperature monitoring system on the egg incubator is ready to operate and can be seen as an effort to realize the system that has been designed.

After all the tools and materials are available, you can assemble each component according to the design that has been made. The following is a picture of the assembled prototype:

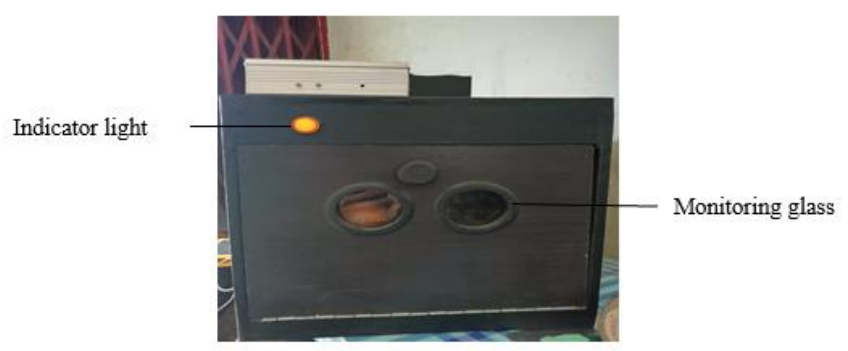

Figure 1 Prototype results of the egg incubator seen from the front

In the display above is the prototype that looks from the front, it has one door and 2 monitoring mirrors to see the condition of the eggs from the outside. As well as an indicator light that lights up indicating that the egg incubator is on. For the inner series can be seen in Figure 2.

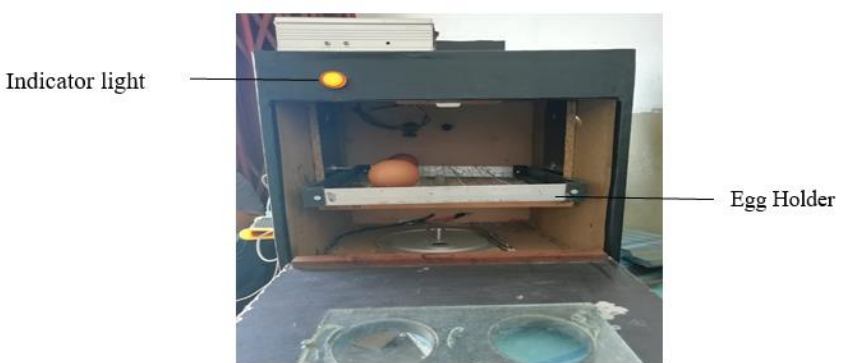

On the inside of the egg incubator, there is a place for laying eggs that has been given a temperature sensor and a heating element. Below the egg laying area is a heating element. The roof of the machine has lights to illuminate from inside the machine. For the top series can be seen in Figure 3 below.

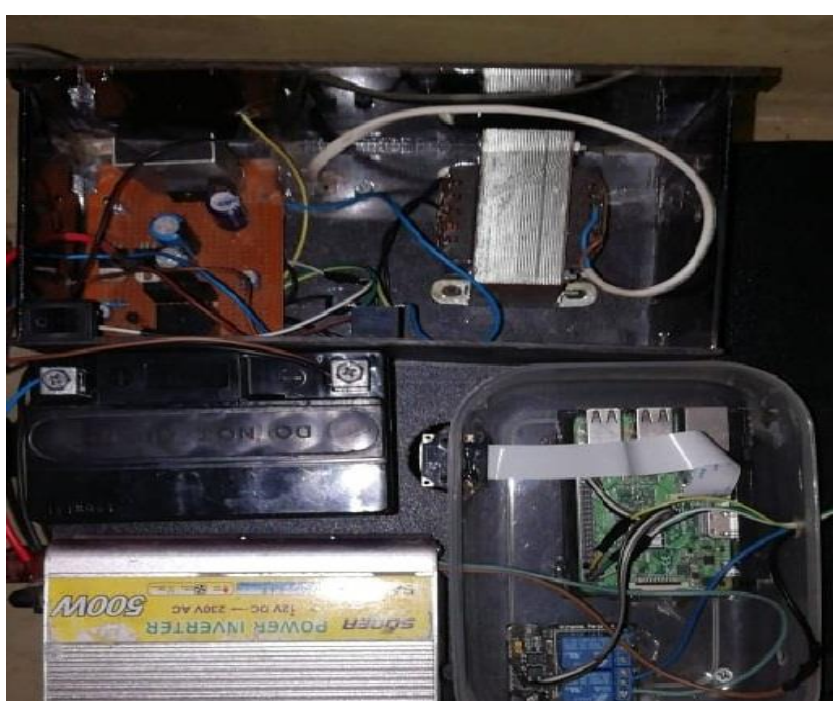

Figure 2 Results of the egg incubator series above

At the top of the egg incubator there are several components including a battery charger circuit, a $12 \mathrm{~V}$ battery, an inverter, a raspberry pi circuit and a webcam camera.

\section{A. Egg Incubator Monitoring Testing}

In testing this tool, the testing technique is done by testing each block of the series and then documented in the form of a picture. The test table, after each series is tested and then the test is carried out as a whole, so that the end of the test is made in the form of a Test Result Evaluation Table and Conclusions from the tests that have been carried out.

\begin{tabular}{|c|c|c|c|c|}
\hline \multirow{2}{*}{ No } & \multirow{2}{*}{ Type of Testing } & \multirow{2}{*}{ Expectation Testing } & \multicolumn{2}{|c|}{ Information } \\
\hline & & & Success & Fail \\
\hline 1 & Circuit Voltage & $\begin{array}{c}\text { The applied voltage can } \\
\text { produce current }\end{array}$ & $\checkmark$ & \\
\hline
\end{tabular}




\begin{tabular}{|c|c|c|c|}
\hline 2 & $\begin{array}{l}\text { Raspberry pi } \\
\text { testing }\end{array}$ & $\begin{array}{l}\text { Raspberry pi can be } \\
\text { activated with Python } \\
\text { programming }\end{array}$ & $\checkmark$ \\
\hline 3 & $\begin{array}{l}\text { DHT Sensor } \\
\text { Testing11 }\end{array}$ & $\begin{array}{l}\text { The sensor detects the } \\
\text { temperature in the } \\
\text { incubator }\end{array}$ & $\checkmark$ \\
\hline 4 & Camera Testing & $\begin{array}{l}\text { The camera can display } \\
\text { eggs in the incubator }\end{array}$ & $\checkmark$ \\
\hline 5 & $\begin{array}{c}\text { Temperature } \\
\text { Control Testing }\end{array}$ & $\begin{array}{l}\text { Temperature control can } \\
\text { be done by application }\end{array}$ & $\checkmark$ \\
\hline 6 & $\begin{array}{c}\text { Login } \\
\text { Application } \\
\text { Testing }\end{array}$ & $\begin{array}{l}\text { Using the application, } \\
\text { you must log in first }\end{array}$ & $\checkmark$ \\
\hline
\end{tabular}

In the table above, the tool works in accordance with the system built, which is successfully displaying the condition of the eggs in the egg incubator and monitoring temperature data.

\section{B. System Testing with the Black-Box Method}

To test the system, the author uses the black-box testing method. This test is carried out to determine whether the program is feasible or not yet to be used and has met the expected needs or not. Black-box testing is a stage that focuses on the functional statement of the software. This test case aims to demonstrate the functionality of the software on how to operate. Whether the temperature data entry, camera and loger data have been running properly. Thus, black-box testing allows software developers to obtain a set of input conditions that fully utilize all functional requirements for a program.

Black-box testing tries to find errors in several ways, namely:

a. Improper or incorrect functions.

b. Interface error.

c. Performance error.

The following table describes the black-box testing method in the application. Tests are carried out on the entire system with certain inputs or conditions.

Table 2. Black-Box Testing.

\begin{tabular}{|c|c|c|c|}
\hline Interface & Input & Output & Conclusion \\
\hline Temperature & $\begin{array}{c}\text { Carry out } \\
\text { the } \\
\text { temperature } \\
\text { command } \\
\text { according } \\
\text { to what has } \\
\text { been } \\
\text { determined }\end{array}$ & $\begin{array}{c}\text { Temperature } \\
\text { is } \\
\text { appropriate }\end{array}$ & Valid \\
\hline
\end{tabular}

\begin{tabular}{|c|c|c|c|}
\hline $\begin{array}{c}\text { Webcam } \\
\text { camera }\end{array}$ & $\begin{array}{c}\text { Perform } \\
\text { camera } \\
\text { commands } \\
\text { according } \\
\text { to what has } \\
\text { been } \\
\text { determined }\end{array}$ & $\begin{array}{c}\text { Image } \\
\text { appears } \\
\text { accordingly }\end{array}$ & Valid \\
\hline \multirow{2}{*}{ Data loger } & $\begin{array}{c}\text { Perform } \\
\text { data loger } \\
\text { commands } \\
\text { according } \\
\text { to what has } \\
\text { been } \\
\text { determined }\end{array}$ & $\begin{array}{c}\text { Displays } \\
\text { temperature } \\
\text { and } \\
\text { humidity } \\
\text { data }\end{array}$ & Valid \\
& & \\
\hline
\end{tabular}

\section{CONCLUSION}

From the results of tests carried out, the authors can draw conclusions, namely: The webcam camera can display the condition of the eggs in the incubator room. Android smartphones can receive information with a webcam camera during the hatching process. Battery $12 \mathrm{~V}$ can work automatically when the power goes out and when the electricity is live the battery will charge. The data logger can display recapitulated temperature and humidity data.

\section{REFERENCES}

[1] W. S. M. Sanjaya et al., "The development of quail eggs smart incubator for hatching system based on microcontroller and Internet of Things (IoT)," 2018 International Conference on Information and Communications Technology (ICOIACT), Yogyakarta, 2018, pp. 407-411, doi: 10.1109/ICOIACT.2018.8350682.

[2] D. A. Thomas, C. Reji, J. Joys and S. Jose, "Automated Poultry Farm with Microcontroller based Parameter Monitoring System and Conveyor Mechanism," 2020 4th International Conference on Intelligent Computing and Control Systems (ICICCS), Madurai, India, 2020, pp. 639-643, doi: 10.1109/ICICCS48265.2020.9120982.

[3] Muhardi, Muhardi, et al. "Design Of Web Based LMS (Learning Management System) in SMAN 1 Kampar Kiri Hilir." Journal of Applied Engineering and Technological Science (JAETS) 1.2 (2020): 70-76.

[4] L. K. S. Tolentino, E. Justine G. Enrico, R. L. M. Listanco, M. Anthony M. Ramirez, T. L. U. Renon and M. Rikko B. Samson, "Development of Fertile Egg Detection and Incubation System Using Image Processing and Automatic Candling," TENCON 2018 - 2018 IEEE Region 10 Conference, Jeju, Korea (South), 2018, pp. 07010706, doi: 10.1109/TENCON.2018.8650320.

[5] Wahyuni, Refni; Irawan, Yuda. Web-Based Employee Performance Assessment System in PT. Wifiku Indonesia. Journal of Applied Engineering and Technological Science (JAETS), 2020, 1.2: 60-69.

[6] Lenardo, Gilang Citra, et al. Pemanfaatan Bot Telegram sebagai Media Informasi Akademik di STMIK Hang Tuah Pekanbaru. JTIM: Jurnal Teknologi Informasi dan Multimedia, 2020, 1.4: 351-357.

[7] S. Gutiérrez, G. Contreras, H. Ponce, M. Cardona, H. Amadi and J. Enríquez-Zarate, "Development of Hen Eggs Smart Incubator for Hatching System Based on Internet of Things," 2019 IEEE 39th Central America and Panama Convention (CONCAPAN XXXIX), Guatemala City, Guatemala, 2019, pp. 1-5, doi: 10.1109/CONCAPANXXXIX47272.2019.8976987.

[8] Irawan, Y., Fernando, Y., \& Wahyuni, R. Detecting Heart Rate Using Pulse Sensor As Alternative Knowing Heart Condition. Journal of Applied Engineering and Technological Science (JAETS),2019, 1(1), pp 30-42.

[9] T. A. Bhuiyan, C. Sevcencu, J. J. Struijk, J. K. Kanters and C. Graff, "Electrocardiographic measurements of the QT interval during embryonic development in fertilized chicken eggs," 2016 Computing in Cardiology Conference (CinC), Vancouver, BC, 2016, pp. 10531055.

[10] Irawan, Yuda, Yunior Fernando, and Refni Wahyuni. "Detecting Heart Rate Using Pulse Sensor As Alternative Knowing Heart 
Condition." Journal of Applied Engineering and Technological Science (JAETS) 1.1 (2019): 30-42.

[11] A. Faroqi, M. R. Efendi, D. T. Ismail and W. Darmalaksana, "Design of Arduino Uno Based Duck Egg Hatching Machine With Sensor DHT22 and PIR Sensor," 2020 6th International Conference on Wireless and Telematics (ICWT), Yogyakarta, Indonesia, 2020, pp. 1-4, doi: 10.1109/ICWT50448.2020.9243640.

[12] L. K. S. Tolentino, E. Justine G. Enrico, R. L. M. Listanco, M. Anthony M. Ramirez, T. L. U. Renon and M. Rikko B. Samson, "Development of Fertile Egg Detection and Incubation System Using Image Processing and Automatic Candling," TENCON 2018 - 2018 IEEE Region 10 Conference, Jeju, Korea (South), 2018, pp. 07010706, doi: 10.1109/TENCON.2018.8650320.

[13] Irawan, Yuda. Penerapan Data Mining Untuk Evaluasi Data Penjualan Menggunakan Metode Clustering Dan Algoritma Hirarki Divisive Di Perusahaan Media World Pekanbaru. Jurnal Teknologi Informasi Universitas Lambung Mangkurat (JTIULM), 2019, 4.1: 13-20.
[14] Wahyuni, Refni, et al. Water Level Control Monitoring Based On Arduino Uno R3 Atmega 238p Using Lm0161 LCD at STMIK Hang Tuah Pekanbaru. Journal of Robotics and Control (JRC), 2020, 2.4: 265-269.

[15] TUNGGAL, Tatiya Padang, et al. Prototype of Hand Dryer with Ultraviolet Light Using ATMega8. Journal of Robotics and Control (JRC), 2019, 1.1: 7-10.

[16] AZAHAR, Kaiyisah Baiduri; SEKUDAN, Ericka Ensimau; AZHAR, Ahmad Mirza. Intelligent Egg Incubator. International Journal of Recent Technology and Applied Science, 2020, 2.2: 91-102.

[17] FERNÁNDEZ-S, Ángel, et al. Electronic system for the detection of chicken eggs suitable for incubation through image processing. In: World Conference on Information Systems and Technologies. Springer, Cham, 2019. p. 208-218.

[18] Rahmalisa, Uci, et al. Detector Leakage Gas Lpg Based On Telegram Notification Using Wemos D1 and Mq-6 Sensor. Journal of Robotics and Control (JRC), 2020, 2.4: 287-291. 